\title{
Research on Cultivating Innovative Talent for International Economics and Trade Based on CDIO Concept
}

\author{
Ruirong Wang, Shouhua Gao \\ Department of International Business \\ Shaoxing Vocational \& Technical College \\ Shaoxing, China \\ e-mail: wrr1978@126.com
}

\author{
Zhibin Li \\ Department of Physics and Electronic Information \\ Shaoxing University \\ Shaoxing, China \\ e-mail: zbli@usx.edu.cn
}

\begin{abstract}
With the deepening of globalization and the sustained and rapid development of international trade, the need for international trade talents becomes larger and larger, and for innovative talent of international economics and trade becomes stronger and stronger. How to keep pace with the development of society and cultivate innovative talents turns out to be an important problem for scholars. CDIO is a new concept for engineering education. In this paper, the problems in the process of vocational education for international economics and trade are discussed, and some countermeasures based on CDIO concept are given in order to .cultivate innovative talents.
\end{abstract}

Keywords-CDIO Concept; International Economics and Trade; Innovative Talents; Vocational Education

\section{INTRODUCTION}

In case of the slowdown in global economic recovery, most companies have to reduce the staff in order to save cost. Obtaining employment becomes a difficult problem for the graduates majored in International Economic and Trade. With the acceleration of the globalization of export enterprises in China, the requirement for the quality of foreign trade personnel is increasing, especially the need of innovative talent becoming quite urgent. Lack of innovative ability in vocational education will result in negative impact on obtaining employment competitiveness and sustainable development capacity of students. Therefore, the study and practice of cultivating creative talents of international economic and trade professionals based on CDIO concept is of important practical significance, which adopts the basic principles of system life cycle-conception, design, implementation, running as educational background, to cultivate students majored in international economics and trade to gain the necessary skills, knowledge and creativity. All these match the requests and needs of the development of the ages.

\section{THE PRESENT SITUATION OF INNOVATIVE EDUCATION IN INTERNATIONAL ECONOMICS AND TRADE}

Innovative talents are the persons with a spirit of innovation, that is to say the persons must own creative personality, innovative thinking, innovative learning quality and social competence[1]. A person is not born with these abilities, but he can acquire them gradually through education and social practice. However, there are still some problems existing in cultivating innovative talents, the main of which are listed as follows.

A. Greatly influenced by traditional education philosophy, innovative education concept hasn't been fully established.

In vocational colleges, most students own rich humanistic knowledge and great innovation potential. The key to stimulating the potential lies in college education. Because of the influence of traditional concept of vocational education in China, there is an idea that the cultivation of students' innovative ability is the responsibility of university and research institutions. And vocational colleges with the duty of cultivating the applied and skilled person do not need to pay attention to the cultivation of students' innovative ability. If we do not change traditional concepts of education, innovation of vocational education will be unnecessary. Therefore, the change of educational concept is the premise of cultivating innovative talents in the major of international economics and trade

\section{B. Curriculum setting is unreasonable.}

International Economics and Trade is a major with strong practicability, the courses of which should focus on students' vocational ability, instead of too much emphasis on discipline, systematicness. The present curriculum in China fails to stress the main points and the curriculum covers wide ranges, which can not meet the requirement of the development of international trade. In the case of fixed teaching hours and credit, in order to achieve the purpose of "broad knowledge and solid foundation ", it is easy to result in such phenomenon, that is to take one thing into consideration and neglect the other one, and finally professional basic courses and professional class hours have to be cut down. Talents should own solid and systematic theory and reasonable professional knowledge, otherwise, the innovation of international trade is just an illusion[2].

C. With imparting knowledge to students for the main part of teaching process, the cultivation of comprehensive abilities has been deficient.

In traditional teaching of International Trade in China, teachers have always attached great importance to the imparting of knowledge. Students gain complete professional discipline system knowledge after completing the learning process. But after all, there is a very large gap between 
tiresome grind and practical work. As a result, once students participate in work, problem will turn out. The employers often complain that graduates do not have a sense of teamwork, lack of interpersonal communication skills. At the same time, narrow professional knowledge in college education makes students lack knowledge and the vision of control system and ability in practical work. It is difficult for them to adapt to complex international trade environment.

\section{Student's innovation ability is weak, practice teaching} becomes a weak point in education.

Under the influence and guidance of cultivating objective and methods in traditional talents of economics and trade, talents from vocational college are lack of innovation ability. Classroom teaching is the place to educate students' theoretical knowledge and practical innovation capacity should be achieved mainly through practical teaching. At present, practical teaching in most vocational colleges in china is weak, which is mainly presented as the lack of effective practice teaching platform, so that the students are short of the process of perceptual cognition to reasonable cognition. Even if Students can enter trade companies for internship, however, because of involving in commercial confidential information, student can't deeply understand the whole business process, let alone doing business by themselves. Therefore, students can only do some simple work just as water boy. There is no essential difference between internship and no internship. Students usually just acquire knowledge on book and memorize specific business processes, which can not efficiently help them improve the capability of solving practical problems.

\section{E. Assessment methods are unsuited to the cultivation of innovative talents.}

At present, for achievement assessment for students majored in international economics and trade of vocational college in china, the normal way is to adopt close-book examination for core curriculum in final examination, and for a small part of field trips, through teachers' applying, the students can submit integrated project or curriculum papers for teachers to test their teaching effect. It seems that such assessment method has the advantage of enhancing standardization and fairness of assessment. But the shortcomings are mainly presented to be weakening the students' innovative thinking, and there is no good for the cultivation of innovative talents. [3]

\section{THE CONNOTATION OF CDIO}

CDIO is short of conceive, design, implement, and operate. Its Initiative is an educational framework for engineering education. As fundamental part of syllabus[4], it integrates active learning methods. It is the centralized summarization and the abstract expression of "learn by doing" and "based on project teaching". It emphasizes the main body of students who can actively explore knowledge and the teacher plays a role as a guider rather than a director of students. It uses product life cycle of CDIO as educational background, taking engineering practice as the carrier, developing the students' ability of mastering basic engineering knowledge and operating ability. Innovation can be guided in the development process of new products, and students can understand the important impact of research and technology development on society, which can help them bear social responsibility as engineering science and technology talents[5]. More importantly, it puts forward twelve rules such as system ability training, guidance for implementing and strict inspection of the results etc., which has very strong operability[6]. CDIO is a concept of talents cultivating which combines theoretic teaching and practical teaching. Ability training objectives of CDIO syllabus and quality requirement of innovative talents have high consistence. Up to now, dozens of world famous universities have joined the CDIO organization, and adopted CDIO engineering education concept, under which the innovation ability of students has been enhanced and graduates have got a high degree of social acceptance and the gaining employment rate of graduates generally has been improved.

The basic principle of CDIO model is simple, which has very strong maneuverability and broad adaptability [7]. CDIO concepts also apply to the major of international economics and trade. International economics and trade is a major with the characteristics of high practice which is closely integrated with society, industry and enterprises, and the content of many practice courses includes business processes, the plan, design and actual production and operation, therefore, it is suitable for CDIO concept. Applying CDIO concept to cultivating innovative and highskilled talents in international trade field embodies the requirement of the era.

\section{EXPLORATION OF INNOVATIVE TALENTS}

CULTIVATING IN INTERNATIONAL ECONOMIC AND TRADE BASED ON CDIO

\section{A. Change teaching concept}

Traditional teaching concept has great influence in vocational colleges in China, which is "teacher-centered", and students accept knowledge passively with little communication with teachers. The teaching content mainly focuses on theoretic knowledge and ignores the cultivation of practice abilities. The content of assessment is also on book knowledge without practice competence assessment. These traditional concepts completely run in the opposite direction with CDIO education concept. Thus before referring to the CDIO, colleges should pay attention to create an atmosphere and environment of good for cultivating innovative talents to improve humanistic environment and form an academic atmosphere helpful for innovation, all of which can create conditions for excellent talents to stand out. The colleges should also establish education evaluation system beneficial for innovation talents and change the assessment content to innovation ability.

\section{B. Optimizing course system}

Traditional teaching concept has great influence in vocational colleges in China, which is "teacher-centered", and students accept knowledge passively with little communication with teachers. The teaching content mainly 
focuses on theoretic knowledge and ignores the cultivation of practice abilities. The content of assessment is also on book knowledge without practice competence assessment. These traditional concepts completely run in the opposite direction with CDIO education concept. Thus before referring to the CDIO, colleges should pay attention to create an atmosphere and environment of good for cultivating innovative talents to improve humanistic environment and form an academic atmosphere helpful for innovation, all of which can create conditions for excellent talents to stand out. The colleges should also establish education evaluation system beneficial for innovation talents and change the assessment content to innovation ability.

\section{Reforming teaching method}

Teaching methods should be gradually gradated from inculcative method to heuristic methods, focusing on student's independent thinking, divergent thinking, making use of various methods to teach students, giving them a fish is not better than teaching them how to fish[8]. Project teaching method of CDIO mode requires students to participate in planning and design of the project. On one hand, it is good for the development of student's creative thinking, understanding of practice in work flow of foreign trade. On the other hand, it also requires teachers to break away out of knowledge learned from books and according to actual foreign trade situation to solve various kinds of problems put forward by students. At the same time, both students and teachers should increase positive interaction; The teachers should encourage students to learn knowledge, be resolute to have practice and the behavior of students can also promote the improvement of teaching level and professional ability of students. Project of practice had better come from a true foreign trade enterprise project, only through which can teachers and students understand the latest trade demand and skill requirements, and learn how to solve practical problems such as management, marketing, interpersonal relationships and so on.

\section{Strengthening practice teaching}

The related discipline knowledge and application ability of international economics and trade comes from social practice and professional quality needs to be cultivating in social practice. Practical teaching is especially important to cultivating innovative talents. The present situation of weak practical teaching in international economics and trade has seriously restricted the cultivation of innovative talents. If we want to cultivate high-quality innovative talents of international trade, we must strengthen the practical teaching link, formulate feasible practical syllabus and combine practical teaching resources, ensure the time of practical teaching, increase the investment of practical teaching. We should focus on building existing practice base inside and outside the college, and continue to find and develop new practice base. We should also advocate the combination of industry-education-research, and carry out college-enterprise and intercollegiate cooperation, and then establish stable cooperation relations.

\section{E. Reforming of assessment system}

Vocational education under CDIO mode is not to check the learning effect of students through professional examination, but to assess the ability of the students by conjunction with projects. In order to make CDIO teaching mode properly implemented, it is important to reform the assessment methods of student achievements [9]. We should reform traditional assessment methods and establish student learning-centered and courses evaluation system fusing several assessment methods. In order to evaluate the students objectively and accurately, all the courses and corresponding knowledge should be assessed in the design of projects. At the same time, because most of the projects come from foreign trade enterprises, evaluation for students should also be combined with the project effect evaluation of foreign trade enterprises, only by this can comprehensive and integrated evaluation results.

\section{CONCLUSION}

With reference to the engineering education concept of CDIO to explore talents cultivation model in international trade, from which students, teachers and enterprise can benefit a lot, the practice base in college and enterprise can effectively combined with each other and waste by repeated education can be avoided. It gives vitality to practice teaching of international trade[10]. Meanwhile, CDIO concept is mainly used in personnel training in engineering specialty, which has not been applying to the development of vocational education in china for a long time. CDIO mode has been applied less in economic majors. Due to the lack of experience, the application of CDIO mode should be improved and perfected constantly during exploration and practice in the future.

\section{ACKNOWLEDGMENT}

This work is supported by Education Programmed Research Projects of Zhejiang ( Grant No. SCG324) and the Scientific and Technological Research Projects of ShaoXing (Grant No. 2011A21053).

\section{REFERENCES}

[1] Shuanrong Liang, "On the Connotation of Conception of Innovative Talent,” Productivity Research, Oct. 2011, PP. 23-26.

[2] Hansong Wu, "Study on Quality, Ability and Knowledge Structure of The Applied Talents in International Trade Major," Vocational Education Research, May. 2006, PP. 146-147.

[3] Jianguo liu, "The Training of Innovative Talents And Examination Reform in Colleges and Universities,” Modern University Education, Feb. 2006, PP. 107-110.

[4] Yuanzhi Zuo, Runhua Jiang and Xiaoping Yang, "On the Innovative Design-oriented CDIO Engineering Education Model,” Journal of Dongguan University of Technology, Mar. 2010, PP. 118-122.

[5] Anssi Ikonen, Antti Piironen and Kimmo Saurén, "CDIO Concept in Challenge Based Learning," WESS '09 Proceedings of the 2009 Workshop on Embedded Systems Education, PP. 27-32.

[6] Jianzhong Zha, "On CDIO Model under "Learning by Doing”Strategy,” Research in Higher Education of Engineering, Mar. 2008, PP. 1-6. 
[7] Xiao Dan, "Exploration of CDIO Model for Engineering Education in Training the Ability of Social Work," Modern Education Science, Feb. 2011,PP. 101-104.

[8] Pingge Zhang, "Chatting educational reform of"hydraulic transmission and control"curriculum with the CDIO pattern,"Chinese Hydraulics \& Pneumatics, Aug. 2010, PP. 14-16.

[9] Wenwen Zhang, "Research on Teaching in Tourism Management Based on CDIO Model," Education Teaching Forum, 2010,PP. 163.

[10] Qi Shen., Yan Zhang and Xianghong Tian, "Constructing Practice Teaching System Refer to CDIO Model,” Computer Education, 2010, PP. 57-60. 